\title{
Erratum to: The Myth of Efficiency: Technology and Ethics in Industrial Food Production
}

\author{
Diana Stuart • Michelle R. Worosz
}

Published online: 10 November 2012

(C) Springer Science+Business Media Dordrecht 2012

\section{Erratum to: J Agric Environ Ethics DOI 10.1007/s10806-011-9357-8}

The Editor regrets the following erratum text went applicable:

Due to an oversight at revision one of the initiating authors had been given a defective family name.

The appropriate name of the author is Michelle R. Worosz.

The online version of the original article can be found under doi:10.1007/s10806-011-9357-8.

\section{Stuart $(\bowtie)$}

Kellogg Biological Station and Department of Sociology, Michigan State University, 3700 East Gull Lake Drive, Hickory Corners, MI 49060, USA

e-mail: dstuart@msu.edu

\section{R. Worosz}

Department of Agricultural Economics and Rural Sociology, Auburn University,

306A Comer Hall, Auburn, AL 36849, USA 